\author{
MARTIN PRACNÝ \\ Uniwersytet Masaryka w Brnie \\ martinpracny@gmail.com \\ ORCID: 0000-0001-5613-3740
}

\title{
Czechosłowacka reforma walutowa z 1953 roku
}

\section{Czechoslovak monetary reform of 1953}

Streszczenie. Celem niniejszego tekstu jest przybliżenie i przedstawienie przyczyn przeprowadzania reformy walutowej, która miała miejsce w 1953 roku w komunistycznej Czechosłowacji, oraz opisanie jej prawnych i technicznych aspektów. Podstawą opracowania będzie analiza prawno-dogmatyczna oraz historyczno-prawna aktów prawnych wprowadzonych w trakcie realizacji reformy oraz innych rządowych dokumentów.

Słowa kluczowe: komunizm; reforma walutowa; Czechosłowacja.

\begin{abstract}
This paper aims to approximate and analyse the reasons of the currency reform that took place in 1953 in communist Czechoslovakia, as well as to describe its legal and technical aspects. The basis of the study will be legaldogmatic and historical-legal analyses of legal acts introduced during the implementation of the reform and other government documents.
\end{abstract}

Keywords: communism; currency reform; Czechoslovakia. 


\section{Uwagi wprowadzające}

Reforma walutowa jest skomplikowanym i kosztownym procesem ekonomicznym, który polega na tym, że wartość waluty lub też sama waluta zmieniają się na danym terytorium w wyniku interwencji władzy państwowej lub innych organów posiadających władzę. Encyklopedia ekonomiczna opisuje warunki zmiany krajowego systemu pieniężnego, które są konieczne, by doszło do reformy walutowej. Warunki te muszą określać:

1. nazwę jednostki monetarnej, jej rodzaj i strukturę;

2. stosunek jednostki monetarnej do metali szlachetnych;

3. skalę cen i związany z nią parytet walutowy oraz kurs wymiany;

4. zasady emisji i obiegu pieniędzy ${ }^{1}$.

Reforma musi obejmować wszystkie wymienione wyżej aspekty. $Z$ reguły potrzeba przeprowadzenia reformy walutowej wynika ze skomplikowanej sytuacji gospodarczej danego państwa (np. podczas wojny), która zakłóca funkcjonowanie krajowego systemu pieniężnego. Biorąc to pod uwagę, można stwierdzić, że reformy walutowe, które miały miejsce po drugiej wojnie światowej, nie były niczym nadzwyczajnym ${ }^{2}$. Ich głównym celem było wyeliminowanie skutków wojny w obiegu pieniężnym i przywrócenie równowagi pieniężnej. W państwach, które po drugiej wojnie światowej musiały obrać ścieżkę socjalizmu, reformy służyły zmianom struktury społeczno-ekonomicznej społeczeństwa. Czechosłowacja nie była wyjątkiem. W 1945 roku przeprowadzono reformę walutową, która miała na celu zmniejszenie ilości pieniędzy w obiegu i przywrócenie korony czechosłowackiej (Kčs), wprowadzonej w 1919 roku. Zadaniem powojennych działań było ostateczne rozwiązanie problemów monetarnych państwa, do czego w konsekwencji niestety nie doszło. Bowiem już kilka lat później miała miejsce kolejna reforma, którą to rząd komunistyczny, chcąc ukryć własne niepowodzenia, określił celowo mianem „reformy pieniężnej”, mimo że formalnie spełniała wyżej wymienione warunki reformy walutowej. Co ciekawe, podobną reformę przeprowa-

S. Adamec, J. Jelínek, Ekonomická encyklopedie 2., P-Ž, Praga 1984, s. 539.

Po drugiej wojnie światowej przeprowadzona została reforma walutowa we wszystkich państwach europejskich z wyjątkiem Wielkiej Brytanii, Szwajcarii, Szwecji i państw leżących na Półwyspie Pirenejskim. 
dzono kilka lat wcześniej, a dokładnej w 1950 roku, w Polsce. Podobieństwa obu reform i chęć opisania sytuacji w Czechosłowacji, o której nie ma zbyt wielu informacji w polskich źródłach, były główną motywacją do napisania tego artykułu.

Przedmiotem niniejszego opracowania jest przybliżenie i przedstawienie przyczyn przeprowadzenia reformy walutowej, której dokonano w 1953 roku w Czechosłowacji oraz opisanie jej prawnych i technicznych aspektów. Podstawą opracowania będzie analiza prawno-dogmatyczna oraz historyczno-prawna aktów prawnych wprowadzonych w trakcie realizacji reformy oraz innych rządowych dokumentów. Analiza ta pozwoli odpowiedzieć na dwa podstawowe pytania: czy istniało inne rozwiązanie niż wprowadzenie reformy walutowej oraz jaki wpływ miała reforma na życie i funkcjonowanie zwykłych obywateli Czechosłowacji?

\section{Przyczyny potrzeby wprowadzenia reformy}

Na początku lat 50. XX w. w Czechosłowacji nastąpił głęboki kryzys gospodarczy, który wynikał z nadmiernego obciążania korony czechosłowackiej nieustannymi wydatkami. Partia Komunistyczna Czechosłowacji, która przejęła absolutną władzę w Czechosłowacji w tzw. praskim zamachu stanu w lutym 1948 roku, wykorzystała swoje przywództwo, aby przekształcić demokratyczny i liberalny system gospodarczy w system socjalistyczny. Podstawą tego systemu miało być centralne zarządzanie wszystkimi procesami gospodarczymi w kraju - wzorem organizacji Związku Socjalistycznych Republik Radzieckich (ZSRR) ${ }^{3}$.

Gospodarka kraju rozwijała się w zawrotnym tempie. Jeszcze przed faktycznym całkowitym przejęciem władzy przez komunistów w październiku 1945 roku znacjonalizowano kluczowy przemysł ciężki, banki akcyjne i zakłady ubezpieczeń. W kolejnych latach w pełni znacjonalizowano górnictwo, elektrownie, gazownie, hutnictwo, walcownie, fabryki broni, cementownie i ważne gałęzie przemysłu chemicznego.

3 F. Vencovský, Vzestupy a propady československé koruny: historie československých měnových poměrů, 1918-1992, Praga 2003, s. 122. 
W konsekwencji około 3000 przedsiębiorstw (około 67\% całości) zostało znacjonalizowanych. Pierwszy plan pięcioletni ${ }^{4}$ (1949-1953) bazował na olbrzymich inwestycjach w przemysł ciężki, który pochłonął połowę wszystkich państwowych wydatków. Budowano elektrownie, huty i fabryki, by zapewnić potrzebne wyposażenie wojsku. Rząd komunistyczny kładł wielki nacisk na stworzenie rozwiniętych sił zbrojnych w związku z tzw. zimną wojną pomiędzy blokiem wschodnim, na którego czele stał ZSRR, a państwami zachodnimi pod przywództwem Stanów Zjednoczonych. Z tego właśnie powodu w 1952 roku w Czechosłowacji produkcja na rzecz wojska stanowiła aż 30\% całego przemysłu maszynowego ${ }^{5}$. Problem pojawił się w momencie, w którym znaczna część produkcji czechosłowackiej zostawała przeznaczana państwom tworzącym od 1949 roku Radę Wzajemnej Pomocy Gospodarczej (RWPG ${ }^{6}$ ). Czechosłowacja została głównym dostawcą przemysłu maszynowego dla reszty krajów RWPG, w których, z wyjątkiem ZSRR, rolnictwo górowało nad produkcją przemysłową. Sytuacja ta doprowadziła do błędnego koła. Czechosłowacja produkowała towary dla innych krajów, jednocześnie nie otrzymując żadnego ekwiwalentnego wynagrodzenia - ani w formie pieniędzy, ani w formie towaru. Konsekwencją tych działań był rosnący dług wewnętrzny państwa.

Stopniowo rosła również dysproporcja między wyraźnie preferowanym przemysłem ciężkim i rolnictwem a przemysłem lekkim. W momencie, gdy siła nabywcza ludności wzrosła, zmniejszyła się ilość produktów konsumenckich. Ludzie nie mieli na co wydawać zarobionych pieniędzy. Doprowadziło to do masowego gromadzenia środków finansowych przez społeczeństwo, co mogło spowodować wzrost inflacji.

Władza komunistyczna zdawała sobie sprawę, że państwo znajduje się na krawędzi bankructwa, co w kontekście politycznym było bardzo

4 Pięcioletni plan był podstawową koncepcją ekonomiczną ZSRR i innych krajów bloku wschodniego.

5 M. Palíšková, Měnová reforma byla politickým krokem [w:] M. Loužek (red.), Fenomén Stalin: náhoda nebo nevyhnutelnost?; Padesát let od měnové reformy: sborník textů, Praga 2003, s. 133.

$6 \quad$ Założycielami Rady Wzajemnej Pomocy Gospodarczej powstałej 5 stycznia 1949 roku były państwa: Bułgaria, Czechosłowacja, Węgry, Polska, Rumunia oraz ZSRR. W późniejszym czasie dołączyły również Albania (1949), Niemcy Wschodnie (1950), Mongolia (1962), Kuba (1972) i Wietnam (1978). 
niepożądane. W kręgach władzy zaczęto głośno komentować sytuację stwierdzono, że zła sytuacja ekonomiczna wynikała głównie z niewystarczająco zaangażowanej ludności pracującej ${ }^{7}$. To z kolei miało mieć związek z wciąż istniejącym w Czechosłowacji systemem reglamentacji ${ }^{8}$. Do zakupu żywności i niektórych towarów przemysłowych oprócz pieniędzy potrzebne były też kartki. Same ceny, szczególnie ceny żywności, były bardzo niskie, ponieważ ustalane były przez państwo. Podjęto decyzję o ustanowieniu wewnętrznego wolnego handlu ${ }^{9}$ poprzez usunięcie systemu reglamentacji. Miało to na celu podwyższenie cen towarów i zwiększenie motywacji zatrudnionych do pracy. W tej trudnej sytuacji dużym problemem okazał się także czarny rynek, przez który państwo traciło znaczne dochody.

Usunięcie systemu reglamentacji groziło gwałtownym wzrostem popytu na towary, które nie były dostępne w sklepach. Zdecydowano zatem, że najprostszym sposobem poradzenia sobie z tym problemem będzie wdrożenie reformy walutowej. Miała ona obniżyć siłę nabywczą ludności i wprowadzić nową walutę razem ze zmianą cen detalicznych w taki sposób, że nawet w przypadku niespodziewanie wysokich zakupów ludności nie mogłyby występować poważne zakłócenia w dostawach. W ten sposób władze gospodarki narodowej nie musiały obawiać się o równowagę między potencjalnym popytem a podażą ${ }^{10}$.

Kolejnym problemem, który trzeba było rozwiązać, był problem deponowanych pieniędzy na rachunkach zablokowanych. W trakcie reformy walutowej z 1945 roku ludność miała możliwość wymiany własnych osz-

7 Z. Jirásek, Čtyři roviny měnové reformy 1953 [w:] M. Loužek (red.), Fenomén Stalin: náhoda nebo nevyhnutelnost?; Padesát let od měnové reformy: sborník textů, Praga 2003, s. 108.

8 System reglamentacji (kartek) został wprowadzony na ziemiach czeskich razem z niemiecką okupacją w 1939 roku i utrzymywał się z niewielkimi modyfikacjami przez 14 lat.

$9 \quad$ Niektóre towary przemysłowe (np. obuwie) i spożywcze można było kupić bez kartek już w styczniu 1949 roku, ceny były jednak znacznie wyższe niż w systemie reglamentacji.

10 M. Tuček, Měnová reforma v mezinárodním kontextu [w:] M. Loužek (red.), Fenomén Stalin: náhoda nebo nevyhnutelnost?; Padesát let od měnové reformy: sborník textů, Praga 2003, s. 112. 
czędności jedynie do kwoty w wysokości 500 Kčs. Pozostałe środki finansowe były deponowane na rachunkach zablokowanych. Uzyskanie pieniędzy zdeponowanych na rachunkach zablokowanych możliwe było jedynie w wyjątkowych okolicznościach, jak na przykład w związku z organizacją ślubu, z okazji urodzenia dziecka, na leczenie, czy też w przypadku inwalidztwa. Pieniądze te udostępniano również przedsiębiorstwom ze względów gospodarczych, takich jak wypłaty wynagrodzeń i niezbędne wydatki związane z funkcjonowaniem przedsiębiorstwa. Narodowy Bank Czechosłowacki otrzymywał aż 700 wniosków dziennie o uwolnienie zdeponowanych pieniędzy. Liczba deponowanych pieniędzy na początku 1953 roku osiągała wysokość około 80 miliardów Kčs, a ich ciągłe uwalnianie do obiegu groziło pogłębieniem się problemów monetarnych.

Komuniści zamierzali jednocześnie pozbyć się pozostałych wrogów socjalizmu - kapitalistów. Przedsiębiorcy oraz chłopi nadał dysponowali znacznymi funduszami. Reforma walutowa stała się zatem narzędziem walki klasowej.

Jak można zauważyć, reformy walutowej nie sposób było uniknąć. Wysoki dług państwa, wciąż istniejący system reglamentacji oraz pieniądze na rachunkach zablokowanych były głównymi przyczynami prowadzącymi do zapoczątkowania reformy. Nadchodzące działania rządu komunistycznego miały zapewnić czystą kartę nowemu socjalistycznemu systemowi zarządzania obiegiem pieniędzy i tym samym całkowicie oddzielić go od systemu poprzedniego ${ }^{11}$.

\section{Przygotowanie reformy}

O wprowadzeniu wolnego handlu wraz z reformą walutową zadecydowano jesienią 1952 roku. Powołana została grupa robocza mająca wypracować plan przeprowadzenia reformy. Grupa ta działała na terenie Polski, by utrzymać reformę w tajemnicy przed obywatelami, a także przed nie-

11 F. Vencovský, Vzestupy a propady československé koruny: historie československých měnových poměrů, 1918-1992..., s. 131. 
którymi członkami rządu ${ }^{12}$. Od grudnia 1952 do marca 1953 roku przygotowywano techniczne zabezpieczenie reformy. Powstały plany transportu i dystrybucji nowych pieniędzy, przygotowano także pierwsze projekty przepisów związanych z reformą. Do finalizacji przygotowań doszło pod koniec maja 1953 roku. Szczegółowo zaplanowano transport i przechowywanie nowej waluty, przygotowywano wydruk niezbędnych dokumentów, zdecydowano o zaangażowaniu wojska i innych sił bezpieczeństwa do przeprowadzenia całej operacji ${ }^{13}$. Ogromny wpływ na ostateczny kształt reformy mieli radzieccy doradcy, którzy od połowy 1950 roku aktywnie pomagali budować socjalistyczną gospodarkę Czechosłowacji. Należy podkreślić, że od 1952 roku w Państwowym Banku Czechosłowackim ${ }^{14}$ zaczął pracować radziecki doradca ekonomiczny Nikołaj Aleksandrowicz Iwanow. Iwanow zwracał uwagę, że waluta czechosłowacka była jedyną walutą bloku sowieckiego w Europie, która nie została jak dotąd związana z rublem, a pozostawała powiązana z dolarem amerykańskim poprzez członkostwo w Międzynarodowym Funduszu Walutowym. Do powiązania nowej waluty czechosłowackiej z rublem radzieckim miało zatem dojść wraz z reformą ${ }^{15}$.

W związku z tym, że Czechosłowacja nie miała wystarczającej zdolności do wyprodukowania niezbędnej ilości nowych znaków pieniężnych, rząd zwrócił się po pomoc do ZSRR. Banknoty o wartości nominalnej $100,50,25$ i 10 Kčs oraz bilety skarbowe o wartości nominalnej 5, 3, 1 Kčs zostały wyprodukowane w radzieckiej drukarni papierów wartościowych Goznak w Moskwie. Natomiast monety halerzowe o nominalnej wartości 25, 10, 5, 3, 1 wybito w Leningradzie (dzisiejszy Sankt Petersburg). Wygląd banknotów, biletów skarbowych i monet został zaprojektowany przez radzieckich artystów. Czechosłowacy wykonali projekty jedynie banknotów o wartości 25, 50, 100 Kčs. Zamówiono łącznie 250

Tamże, s. 132.

13 Z. Jirásek, J. Šůla, Velká peněžní loupež v Československu 1953, aneb, 50:1, Praga 1992, s. 12.

14 Państwowy Bank Czechosłowacki powstał w 1950 roku, zastępując tymczasowy Narodowy Bank Czechosłowacki. Jako bank centralny działał do 1992 roku.

15 Z. Jirásek, Čtyři roviny měnové reformy 1953..., s. 108. 
milionów sztuk papierowych pieniędzy i 450 milionów monet ${ }^{16}$. Produkcja nowych pieniędzy za granicą pomogła jednocześnie w utrzymaniu przygotowań reformy w tajemnicy. Terminowa dostawa pieniędzy nastąpiła 24 maja 1953 roku. Pieniądze były początkowo przechowywane w magazynach wojskowych, a następnie 30 maja 1953 roku zostały przekazane Państwowemu Bankowi Czechosłowackiemu. Ostatecznie dostarczono, w granicach 10\% tolerancji, 256935000 sztuk banknotów o łącznej wartości nominalnej 7 miliardów nowych koron. 8 lipca 1953 roku Czechosłowacja zapłaciła ZSRR za wszystkie usługi około 27 milionów nowych koron ${ }^{17}$. Pod koniec maja 1953 roku reforma walutowa została ostatecznie przygotowana.

\section{Przeprowadzenie reformy i warunki wymiany pieniędzy}

Na początku maja 1953 roku ogłoszono, że najbliższe płace i wynagrodzenia wypłacone zostaną w dwóch terminach. Rząd uzasadnił takie działania potrzebą równomiernej dystrybucji płac i wynagrodzeń. W rzeczywistości jednak połowa przeznaczonych na płace pieniędzy miała zostać wypłacona w starej walucie, tak by ludzie mogli dokonać niezbędnych zakupów, natomiast druga połowa miała zostać wypłacona pracownikom $\mathrm{w}$ formie nowych pieniędzy na początku czerwca po przeprowadzeniu reformy. W społeczeństwie zaczęto dyskutować o tym, że z pieniędzmi będzie działo się coś niepokojącego. Tymczasem rząd komunistyczny zapewniał obywateli, że do żadnej reformy walutowej nie dojdzie. 29 maja 1953 roku czechosłowacki prezydent Antonín Zápotocký w przemówieniu radiowym miał powiedzieć, że czechosłowacka waluta jest silną walutą, dzięki czemu nie dojdzie do reformy walutowej, a wszystkie plotki na ten temat są rozpowszechniane przez wrogów klasowych $^{18}$. Było jednak odwrotnie. W sobotę 30 maja 1953 roku w ciągu

\footnotetext{
Z. Jirásek, J. Šůla, Velká peněžní loupež v Československu 1953, aneb, 50:1..., s. 19-23. Tamże, s. 35.

18 Zapis przemowy nie został zachowany, został prawdopodobnie zniszczony przez komunistów, którzy chcieli zniszczyć dowody sprzeczności przemówienia prezydenta.
} 
jednego dnia uchwalona została przez wszystkie najważniejsze organy państwowe $^{19}$ ustawa o przeprowadzeniu reformy ${ }^{20}$. Wieczorem tego samego dnia ustawę podpisał prezydent, który jeszcze dzień wcześniej negował, jakoby miało dojść do reformy walutowej.

Komuniści reformę tę nazywali reformą pieniężną. Nie używano pojęcia reforma walutowa z tego względu, że do reform walutowych dochodziło zazwyczaj w sytuacjach kryzysów gospodarczych. Komuniści nie chcieli przyznać, że do takiego kryzysu doszło, dlatego też używali innej nazwy w celach propagandowych. Utrzymywali, że dochodzi tylko do wymiany pieniędzy według określonego stosunku, a nie do wprowadzenia nowej waluty ${ }^{21}$. Oficjalne rządowe wyjaśnienie i uzasadnienie przeprowadzenia reformy uwypuklało niedoskonałość działań podjętych przy reformie walutowej z 1945 roku i podkreślało, że obecna reforma jest tak naprawdę walką z pozostałymi kapitalistycznymi wrogami, którzy wzbogacili się kosztem klasy robotniczej.

O reformie poinformowano obywateli w komunistycznym dzienniku Rudé právo w niedzielę 31 maja 1953 roku. Komuniści liczyli na to, że nikt nie będzie w stanie wydać zaoszczędzonych pieniędzy, robiąc zakupy, ponieważ większość sklepów w niedzielę była zamknięta. W miastach zaczęły tworzyć się długie kolejki przed restauracjami, kioskami i kinami. Ludzie próbowali wydać stare pieniądze na cokolwiek, ponieważ zdawali sobie sprawę, że za chwilę staną się bezwartościowymi papierkami.

Ustawa o reformie weszła w życie 1 czerwca 1953 roku, a jej postanowienia zostały przeprowadzone do 4 czerwca 1953 roku. W okresie tym Państwowy Bank Czechosłowacki ściągał z obiegu wszystkie czechosłowackie banknoty oraz monety wprowadzone podczas reformy walutowej w 1945 roku - wymieniał je na nowe czechosłowackie korony oraz halerze w jednym z 7906 miejsc.

19 Rano reformę walutową zatwierdził Komitet Centralny Komunistycznej Partii Czechosłowackiej, przed południem zgodę wyraził rząd, po południu ustawę uchwaliło Zgromadzenie Narodowe.

20 Zákon č. 41/1953 Sb., o peněžní reformě.

21 Z. Jirásek, J. Šůla, Velká peněžní loupež v Československu 1953, aneb, 50:1..., s. 16. 
Sposób przeprowadzenia reformy, który mocno redukował ilość pieniędzy w obiegu, został ustalony na mocy rozporządzenia ministra skarbu z dnia 30 maja 1953 roku $^{22}$. Wynagrodzenia i ceny przeliczano w stosunku 5 starych koron równych 1 nowej koronie. Taki sam stosunek wymiany stosowano w przypadku gotówki - możliwa była wymiana maksymalnie 300 starych koron, a samej wymiany mogły dokonać jedynie osoby i członkowie ich rodzin, którzy nie zatrudniali innych osób i którzy nie zostali wykluczeni z korzystania z systemu reglamentacji ${ }^{23}$ zgodnie z rozporządzeniem Ministra Handlu Wewnętrznego z dnia 13 stycznia 1953 roku $^{24}$. Pozostałe zgromadzone pieniądze (powyżej 300 starych koron) podlegały wymianie w stosunku 50 starych koron równych 1 nowej koronie. Taki stosunek wymiany obowiązywał osoby, które zatrudniały innych lub nie posiadały prawa do wymiany pieniędzy w stosunku 5 starych koron równych 1 nowej koronie.

Oszczędności na książeczkach oszczędnościowych do wysokości 5000 Kčs zostawały przeliczane w stosunku 5 starych koron równych 1 nowej koronie, od 5000 do 10000 Kčs w stosunku 6,25 do 1, od 10000 do 20000 Kčs w stosunku 10 do 1 , od 20000 do 50000 Kčs w stosunku 25 do 1, a ponad 50000 Kčs w stosunku 30 do 1. Pieniądze na książeczkach oszczędnościowych wpłacone po 16 maja 1953 roku, tzn. w momencie, kiedy ludzie zaczęli podejrzewać, że z pieniędzmi będzie się coś działo i próbowali je uratować poprzez złożenie ich do banku, przeliczane były w stosunku 50 do 1 . Co ciekawe wszystkie długi zostały przeliczone w stosunku 5 do 1. Oznacza to, że oszczędności przez różny stosunek przeliczania utraciły swoją wartość, długi natomiast pozostawały.

Pieniądze, które podczas reformy walutowej w 1945 roku były deponowane na rachunkach zablokowanych, zostały anulowane. Pozbyto się mniej więcej 80 miliardów starych koron, które miały formę długu państwowego. Swoją działalność zakończył jednocześnie Likwidacyjny Fun-

\footnotetext{
Směrnice ministra financí č. 159/1953 Ú. l., o způsobu provedení peněžní reformy.

23 Wykluczeni byli na przykład prywatni przedsiębiorcy, czy też prywatni rolnicy, którzy nie spełnili obowiązkowych limitów dostaw mleka, mięsa oraz jajek. Takie osoby nie mogły korzystać z kartek, a towar i żywność musiały kupować za wielokrotnie wyższe ceny.

24 Vyhláška ministra vnitřního obchodu č. 11/1953 Ú. l., o odběru zboží na vázaném trhu.
} 
dusz Walutowy, który dotychczas zarządzał zdeponowanymi pieniędzmi. Anulowane zostały także wszelkie ubezpieczenia w starej walucie, papiery wartościowe w starej walucie oraz państwowe papiery wartościowe bez względu na to, czy zostały wydane przed reformą walutową w 1945 roku, czy po niej.

Jedynym pozytywnym skutkiem, który reforma przyniosła ludziom, było zniesienie systemu reglamentacji oraz możliwość zakupu towaru i żywności w wolnym handlu bez potrzeby posiadania kartek. Nowe ceny detaliczne były jednak dwukrotnie wyższe niż przed reformą. By zrekompensować tę sytuację, podwyższone zostały niektóre wynagrodzenia za pracę oraz świadczenia socjalne ${ }^{25}$. Reformę tę można określić jako denominację nieekwiwalentną. Dochodzi do niej w momencie, w którym ludność wymienia posiadane pieniądze w sposób nieproporcjonalny do poziomu cen.

Za pośrednictwem reformy ustanowiono nową zawartość złota w koronie. 1 Kčs zawierała 0,123426 gramów złota. W zależności od zawartości złota określono również stosunek korony do walut obcych. Dla rządu najważniejsze było ustanowienie kursu do rubla radzieckiego, który wynosił wówczas 1 rubel równy 1,80 Kčs. Na podstawie kursu korony do rubla ustawiony został kurs do innych obcych walut. Na przykład 1 amerykański dolar można było wymienić za 7,20 Kčs ${ }^{26}$. Jednak konwersja ta w stosunku do rubla zawyżała koronę. Prawidłowo, biorąc pod uwagę współczynnik konwersji równy 5 do 1, powinna wynosić 1 dolar amerykański równy 10 Kčs.

\section{Podsumowanie}

Dziennik Rudé právo publikował gloryfikujące artykuły o tym, jak klasa robotnicza z zadowoleniem przyjmuje i świętuje działania rządu. Rze-

25 V. Tomšík, 100 let česko-slovenské koruny: měnová politika, instituce, peníze, Pilzno 2018, s. 33.

26 W latach 1946-1953 kurs wynosił 50 czechosłowackich koron równych 1 amerykańskiemu dolarowi. Oznacza to, że korona za pośrednictwem reformy została rewaluowana o $39 \%$. 
czywistość była jednak nieco inna. W wyniku reformy wybuchły strajki w 129 fabrykach - brało w nich udział 60000 pracowników. Niektóre z nich rozwinęły się w demonstracje. Do największej demonstracji doszło w Pilznie w fabryce Škody. Uczestniczyło w niej 20000 ludzi, 331 z nich zostało następnie skazanych ${ }^{27}$. Były to pierwsze, choć krótkie, próby powstania antykomunistycznego w bloku wschodnim. Większość ludzi postrzegała reformę jako wielką kradzież dokonaną względem obywateli, tym bardziej że członkowie partii komunistycznej często otrzymywali lepsze warunki wymiany.

Reforma silne dotknęła także ostatnich prywatnych rolników, którzy nie zdążyli stać się częścią rolniczych spółdzielni produkcyjnych. Celem komunistycznego rządu była likwidacja prywatnego rolnictwa, dlatego razem z reformą mocno obniżone zostały ceny sprzedawanych produktów rolnych.

W rezultacie $\mathrm{w}$ trakcie reformy $\mathrm{z}$ obiegu wymieniono łącznie 49,1 miliardów starych koron, z całkowej liczby 52,1 miliardów starych koron, które w obiegu pozostawały do 31 maja 1953 roku. Pozostałe 3 miliardy nie zostały zwrócone ze względu na ich zniszczenie, utratę lub wywiezienie za granicę. Całkowita wartość starych koron odpowiadała 1,4 miliarda nowych koron. Na książeczkach oszczędnościowych do 31 maja 1953 roku znajdowało się 31,3 miliardów starych koron, co po przeliczeniu dawało 3,5 miliardów nowych koron. Pod koniec 1953 roku w obiegu było 3,8 miliardów nowych koron, a stan depozytów oszczędnościowych równy był 3,4 miliardom nowych koron. Ludzie często tracili całe swoje życiowe oszczędności. Dla niektórych osób rzeczywista wartość oszczędności zmniejszyła się nawet o 98\%. W wyniku reformy, po odjęciu wydatków związanych z jej przygotowaniem i przeprowadzeniem, państwo uzyskało kosztem własnych obywateli około 3,5 miliarda nowych koron ${ }^{28}$. Mimo to część pozyskanych pieniędzy wykorzystana została na obniżenie cen niektórych towarów. Szacuje się, że w Czechosłowacji w wyniku

\footnotetext{
R. Vondra, Peníze v moderních českých dějinách, Praga 2012, s. 76.

Z. Jirásek, J. Šủla, Velká peněžní loupež v Československu 1953, aneb, 50:1..., s. 86.
} 
reform poziom życia spadł o $15 \%{ }^{29}$. Pomimo prób rekompensaty skutków reformy w postaci obniżek cen żywności oraz towarów, których i tak nadal brakowało w sklepach, a także podwyżek płac, niezadowolenie z reformy utrzymywało się nawet w czasach, gdy poziom życia już przekroczył poziom sprzed reformy. Utrata życiowych oszczędności pozostawała w pamięci obywateli przez cały okres komunistyczny - prowadziło to do częstych pogłosek o nowej nachodzącej reformie.

W związku z tym, że Czechosłowacja, będąca wówczas członkiem Międzynarodowego Funduszu Walutowego i Banku Światowego, nie spełniła swojego obowiązku uprzedzenia o nadchodzących reformach walutowych i nie podała informacji o sytuacji gospodarczej kraju, wzywana była do rezygnacji ze swojego członkostwa w tych organizacjach ${ }^{30}$. Pod koniec 1954 roku Czechosłowacja została wykluczona z obu organizacji ${ }^{31}$.

W sierpniu 1953 roku Ministerstwo Skarbu opracowało raport na temat przeprowadzonej reformy walutowej i jej rozliczeń. Jego celem było dokonanie oceny wyników reformy. Zgodnie z raportem reforma spełniła oczekiwania jej twórców, ponieważ doprowadziła do wyeliminowania wszystkiego, co wiązało się z poprzednim systemem. Umożliwiła także całkowitą transformację czechosłowackiej gospodarki w tzw. socjalistyczny model radziecki. Uzyskane za pomocą reformy pieniądze umożliwiły zwiększenie inwestycji w nadchodzących latach. W 1954 i 1955 roku gospodarka kierowała się planem rocznym, następnie odnowione zostały plany pięcioletnie. Wkrótce okazało się, że gospodarka pomimo dużych inwestycji kapitału oraz pracy roboczej w przemyśle i rolnictwie nie rozwijała się efektywnie. Wynikało to z niedoskonałości gospodarki centralnie planowanej. Niekorzystny wpływ miało również ustalanie planów z góry. Najlepszym tego dowodem może być ponowne pojawienie się ukrytej inflacji ${ }^{32}$ wynikającej z niedającej się zaspokoić siły nabywczej ludności.

29 F. Vencovský, Vzestupy a propady československé koruny: historie československých měnových poměrů, 1918-1992..., s. 133.

30 V. Tomšík, 100 let česko-slovenské koruny: měnová politika, instituce, peníze..., s. 33.

31 Czechosłowacja została ponownie członkiem tych organizacji w 1990 roku.

32 Inflacja ukryta wyrażona jest w trwałej nadwyżce popytu nad ograniczoną podażą dóbr i usług przy administracyjnie regulowanym poziomie cen rynkowych. 
Realizacja reformy z ideologicznego punktu widzenia była prawdopodobnie jedynym możliwym wyjściem z ówczesnej sytuacji. Teoretycznie rzecz biorąc, rosnące niedopasowanie pomiędzy siłą nabywczą ludności a niedostatkiem towarów można było rozwiązać w inny sposób (na przykład zwiększając ceny towarów bez wprowadzenia reformy), ale wówczas nie było to możliwe ze względu na dług wewnętrzny państwa oraz potrzebę usunięcia systemu reglamentacji wraz z pieniędzy na rachunkach zablokowanych i dlatego zadecydowano o wprowadzeniu zmian w najbardziej bolesny dla obywateli sposób.

\section{Bibliografia:}

Adamec S., Jelínek J., Ekonomická encyklopedie. 2, P-Ž, Svoboda, Praga 1984.

Bakeš M., Finanční právo, C.H. Beck, Právnické učebnice, Praga 2012.

Jirásek Z., Čtyři roviny měnové reformy 1953 [w:] M. Loužek (red.), Fenomén Stalin: náhoda nebo nevyhnutelnost?; Padesát let od měnové reformy: sborník textů, Centrum pro ekonomiku a politiku, Praga 2003.

Jirásek Z., Šůla J., Velká peněžní loupež v Československu 1953, aneb, 50:1, Svítání, Praga 1992.

Palíšková M., Měnová reforma byla politickým krokem [w:] M. Loužek (red.), Fenomén Stalin: náhoda nebo nevyhnutelnost?; Padesát let od měnové reformy: sborník textů, Centrum pro ekonomiku a politiku, Praga 2003.

Tomšík V., 100 let česko-slovenské koruny: měnová politika, instituce, peníze, Vydavatelství a nakladatelství Aleš Čeněk, Pilzno 2018.

Tuček M., Měnová reforma v mezinárodním kontextu [w:] M. Loužek (red.), Fenomén Stalin: náhoda nebo nevyhnutelnost?; Padesát let od měnové reformy: sborník textů, Centrum pro ekonomiku a politiku, Praga 2003.

Vencovský F., Vzestupy a propady československé koruny: historie československých měnových poměrů, 1918-1992, Vysoká škola ekonomická, Praga 2003.

Vondra R., Peníze v moderních českých dějinách, Academia, Praga 2012. 